\title{
Creative Thinking Skills within Accounting in College Curriculum of Indonesia
}

\author{
Gayatria Oktalina, Erika Feronika Br. Simanungkalit \\ Students of Economic Education Pascasarjana \\ Universitas Pendidikan Indonesia \\ Bandung, Indonesia \\ gayatria_oktalina@student.upi.edu
}

\begin{abstract}
Merger of Indonesia to the MEA demanding college graduates have high competitiveness, so that the curriculum should encourage students to have a high-level thinking skill one of them is creative thinking. So, this research examines the content and chances of implementing creative thinking skills across the accounting curriculum at colleges, in particular, financial accounting courses intermediate and advanced. Sample researches are State Colleges (PTN) and Private Colleges (PTS) in the Department of accounting in Indonesia is represented by the University of Indonesia (UI) and Gunadarma University (UG). In reviewing the content payload uses the value of creative thinking sections of the Association of American Colleges and Universities as well as to measure the chances of implementation used Threats, Opportunities, Weaknesses, and Strength (TOWS) analysis. Findings in research show the content creative thinking skills on courses of intermediate financial accounting and Advanced, UI is higher than UG. The opportunities for implementing creative thinking skills across the accounting curriculum at PTN and PTS big enough.
\end{abstract}

Keywords-Creative Thinking Skills, Intermediate Financial Accounting, Advanced Financial Accounting, Accounting Curriculum in Colleges

\section{INTRODUCTION}

Many creative thinking skills are generally incorporated into the educational curriculum of technology and science, but nowadays globalization requires every college graduates from various disciplines have the ability to think creatively.

Indonesia joined to the MEA should be the beginning of the educational reform. MEA is closely associated with accounting, accounting is no longer able to rely on rote evidence of accounting, but accounting graduates must also have the skills of creative thinking that can support long-life education.

Stress the importance of skill development during accounting programmes and state that: 'Students forget what they memorize. Content knowledge becomes dated and is often not transferable across different types of jobs. On the other hand critical skills rarely become obsolete and are usually transferable across assignments and careers'[1]. Because on global economy the company should be able to manage creatively finance company in order to survive and compete in today's global economic competition. As a result, employers are seeking a diverse range of skills and attributes in new accounting graduates to maintain a competitive advantage despite the fact that many countries are facing a skills shortage in the area [2]. Therefore, colleges should build creative thinking skills -based curriculum.

In the 21 st century, students are expected to come up with creative thinking skills [3] [4]. However, how students are learning to think creatively if the curriculum is not loading content of it, and the material in the curriculum did not facilitate students to think creatively.

The accounting curriculum requires changes in accounting education towards creating better. A study conducted by Chabrak and Craig shows that the accounting curriculum needs to be reformed, and he suggested to add critical-thinking skills in accounting and awarding creative tasks [5]. Isakses and Pranes also had to give advice to make a curriculum for creative thinking and problem solving. The survey results in Isakses and Pranes from 150 curriculum planners about the knowledge, attitudes and behavior with respect for the development of creative thinking and the ability to solve problems. Based on the findings and conclusions can be noted that the curriculum can provide programs to improve the skills of creative thinking and problem solving [6].

Seeing the developments in the world of work, college accounting majors should produce graduates, which have the skills to process information; able to communicate well; able to cooperate with others; critical and creative thinking. So, from a lot of research on the importance of creative thinking in the college curriculum content especially disciplines of accounting, the reference implementation of this research, but directly focused on the content payload nerve in the accounting curriculum at Indonesian universities and what are the opportunities' application. Curriculum samples taken from two universities, which are stated and private universities with the best accounting majors Indonesia.

University of Indonesia (UI) is a State college in Indonesia, which has the best Accounting Department, version by the National Accreditation Board of Higher Education (BAN-PT). Though the UI has the best accounting Department, curriculum issues are also experienced by the campus. The accounting department realized that the curriculum should continue to be 
refined in order to achieve the nation's goals to have a generation of quality can be realized.

Gunadarma University (UG) is a private college in Indonesia, which has the best Accounting Department, version by the National Accreditation Board of Higher Education (BAN-PT). Same as UI, Gunadarma University also had a problem. Thus, research needs to be done to investigate the content material contained in the accounting curriculum of the Colleges and the opportunities that exist to implement curriculum-based creative thinking skills.

\section{LITERATURE REVIEW}

Curriculum according to Taba is a system or a draft composed in grooved from a study, taking into account all the good things from the learning process as well as on the development within the individual [7]. The curriculum has a close relationship with accounting learning.

TABLE 2.1. A REVISION OF BLOOM'S TAXONOMY

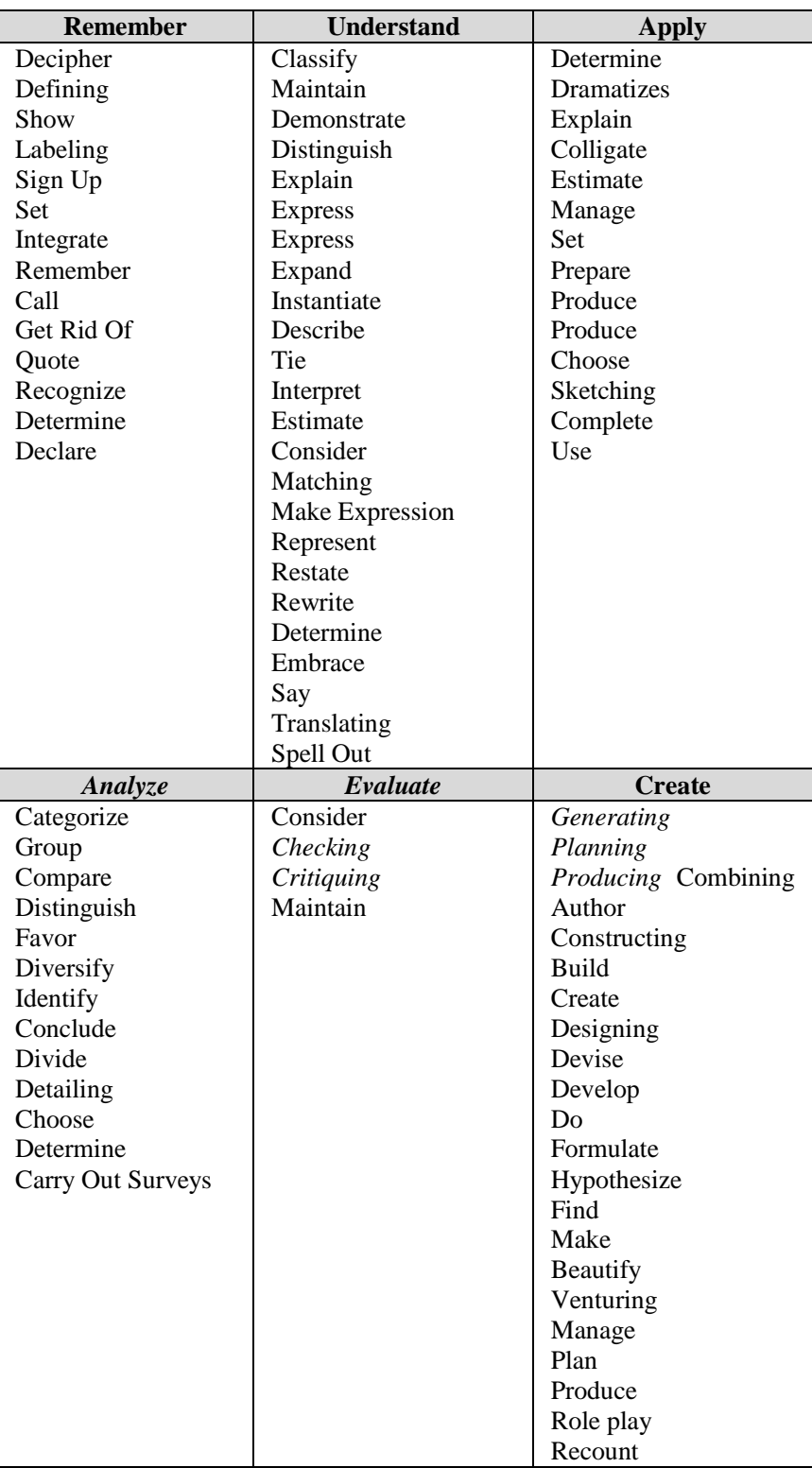

Accounting as majors has the curriculum learning system that includes 19 outline subjects with weight's credit semester system (SKS) amounting to 144 in which there are subjects of financial accounting intermediate and advanced whose aim is to produce graduates who are able to apply their expertise and utilize science and technology in the field problem-solving and able to adapt to the situation at hand, mastering the theoretical concept of a particular area of knowledge in General and theoretical concepts of the special section in the areas of the knowledge in depth as well as being able to formulate a procedural problem solving, able to take the right decisions based in the analysis of information and data, and be able to provide guidance in selecting various alternative solutions groups as well as independently and responsibly on your own work and may be given the responsibility for the achievement of the Organization's work [8].

The Association of American Colleges and Universities revealed that the creative thinking skill was the capacity to combine or synthesize ideas, images, or expertise in a way that is original and thought-provoking experience, react, and imaginative works are characterized by a high level of innovation, divergent thinking, and risk taking [9]. While Bailin says that creative thinking skill is a concept where to apply principles of logical, after a lot of investigations and analysis, to solve the problem with the high level of innovation, divergent thinking and risk-taking. Creative thinking skills are characterized by Acquiring competencies, Solving Problems, Risk Taking, Connecting, synthesizing, Transforming the Innovative Thinking [10]

Based on the revised Bloom's Taxonomy (Table 2.1), creative thinking skills are at the level 6 cognitive [11].

\section{RESEARCH METHODOLOGY}

This research examines the content into the curriculum in intermediate and advanced financial accounting to determine whether the content is already contained within the creative thinking skills as well as to assess the opportunities that exist to apply creative thinking skills. As for our curriculum data taken from a population that numbered 5 private and State colleges majoring in accounting with the best, there is in Indonesia's version of BAN-PT with sampling techniques using purposive sampling that generates two colleges representing By UI (State college) and UG (private college)

Based on this, the researchers' units are University of Indonesia (UI) and Gunadarma University (UG). Research analysis using a descriptive approach and implementation opportunities with Threat, Opportunities, Weakness, and Strength (TOWS). 


\section{RESULTS \& DISCUSSION}

TABLE 4.1. CReative THINKING VALUE RUBRic

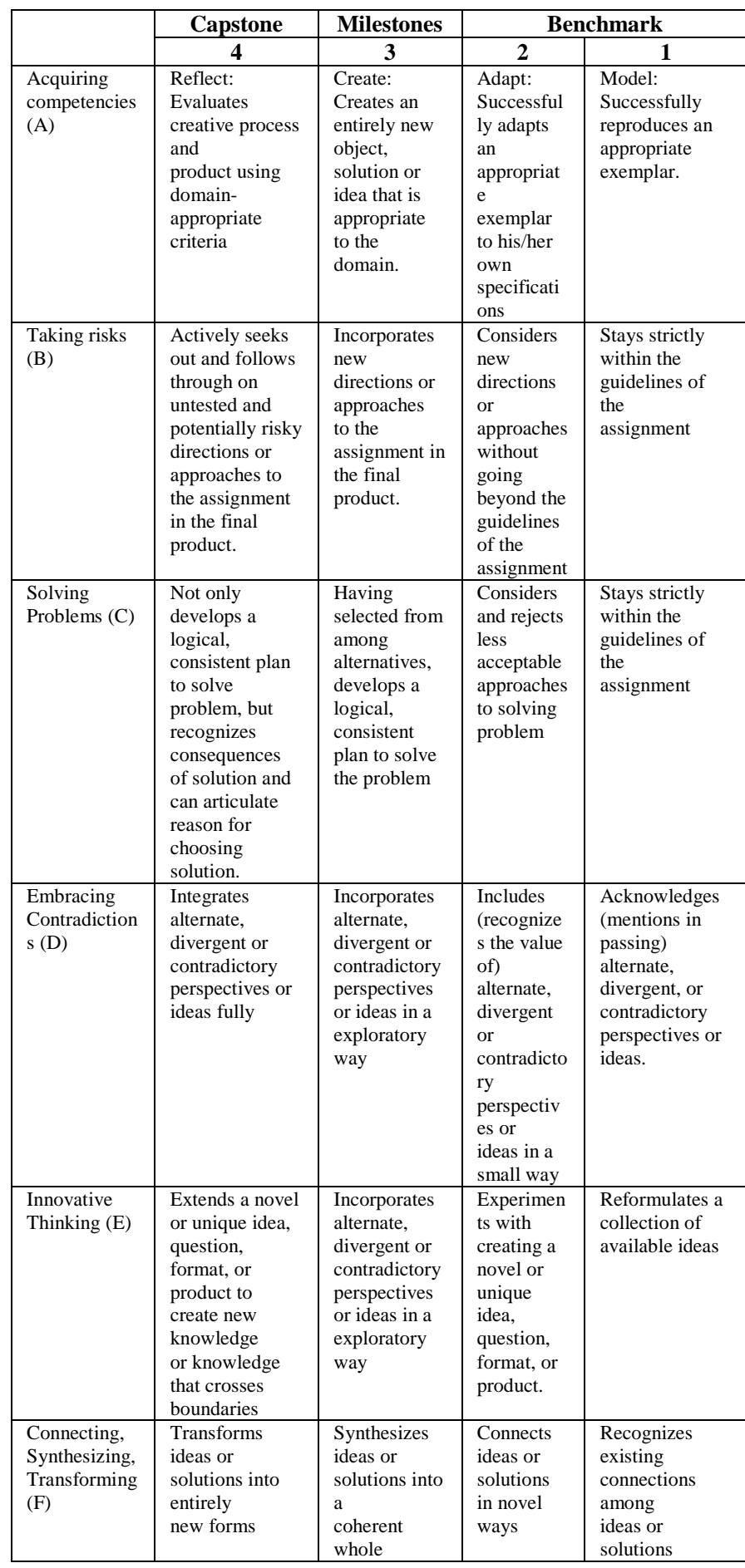

a. Source: Association of American Colleges and Universities [9]

Based on Table. 4.1. Creative Thinking Value Rubric, counting curriculum content within intermediate and advanced financial accounting in Gunadarma University (UG) and University of Indonesia (UI) are as table 4.2: table 4.2. Creative Thinking Skills Content in Intermediate FINANCIAL ACCOUNTING CURRICULUM AND ADVANCED AT GUNADARMA UNIVERSITY (UG)

\begin{tabular}{|c|c|c|c|c|}
\hline \multirow[t]{2}{*}{ Criteria } & \multicolumn{4}{|c|}{ Courses } \\
\hline & & $\begin{array}{c}\text { Intermediate } \\
\text { Financial } \\
\text { Accounting I }\end{array}$ & $\begin{array}{c}\text { Intermediate } \\
\text { Financial } \\
\text { Accounting II }\end{array}$ & $\begin{array}{l}\text { Advanced Financial } \\
\text { Accounting II }\end{array}$ \\
\hline \multirow[t]{4}{*}{ A } & 4 & - & - & - \\
\hline & 3 & - & - & - \\
\hline & 2 & - & - & - \\
\hline & 1 & $7 * 1=7$ & $9 * 1=9$ & $12 * 1=12$ \\
\hline TOTAL & & $7 / 70 * 100=10 \%$ & $9 / 90 * 100=10 \%$ & $12 / 120 * 100=10 \%$ \\
\hline \multirow[t]{4}{*}{ B } & 4 & - & - & - \\
\hline & 3 & - & - & - \\
\hline & 2 & - & - & - \\
\hline & 1 & $7 * 1=7$ & $9 * 1=9$ & $12 * 1=12$ \\
\hline TOTAL & & $7 / 70 * 100=10 \%$ & $9 / 90 * 100=10 \%$ & $12 / 120 * 100=10 \%$ \\
\hline \multirow[t]{4}{*}{$\mathrm{C}$} & 4 & - & - & - \\
\hline & 3 & - & - & - \\
\hline & 2 & - & - & - \\
\hline & 1 & $7 * 1=7$ & $9 * 1=9$ & $12 * 1=12$ \\
\hline TOTAL & & $7 / 70 * 100=10 \%$ & $9 / 90 * 100=10 \%$ & $12 / 120 * 100=10 \%$ \\
\hline \multirow[t]{4}{*}{$\mathrm{D}$} & 4 & - & - & - \\
\hline & 3 & - & - & - \\
\hline & 2 & - & - & - \\
\hline & 1 & - & $2 * 1=2$ & $12 * 1=12$ \\
\hline TOTAL & & - & $2 / 90 * 100=2,2 \%$ & $12 / 120 * 100=10 \%$ \\
\hline \multirow[t]{4}{*}{$E$} & 4 & - & - & - \\
\hline & 3 & - & - & - \\
\hline & 2 & - & - & - \\
\hline & 1 & - & $4 * 1=4$ & $7 * 1=7$ \\
\hline TOTAL & & - & $4 / 90 * 100=4,4 \%$ & $7 / 120 * 100=5,83 \%$ \\
\hline \multirow[t]{4}{*}{$\mathrm{F}$} & 4 & - & - & - \\
\hline & 3 & - & - & - \\
\hline & 2 & - & - & - \\
\hline & 1 & - & - & $6 * 1=6$ \\
\hline TOTAL & & - & - & $6 / 120 * 100=5 \%$ \\
\hline SUM & & $21 / 420 * 100=5 \%$ & 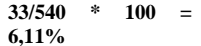 & $61 / 720 * 100=8,47 \%$ \\
\hline
\end{tabular}

TABLE 4.3. CREATIVE THINKING SKILLS CONTENT IN INTERMEDIATE FinANCIAL ACCOUNTING CURRICULUM AND ADVANCED AT UNIVERSITY OF INDONESIA (UI)

\begin{tabular}{|c|c|c|c|c|}
\hline \multirow[t]{2}{*}{ Criteria } & \multicolumn{4}{|c|}{ Courses } \\
\hline & & $\begin{array}{c}\text { Intermediate } \\
\text { Financial Accounting } \\
\text { I }\end{array}$ & $\begin{array}{c}\text { Intermediate } \\
\text { Financial } \\
\text { Accounting II }\end{array}$ & $\begin{array}{l}\text { Advanced Financial } \\
\text { Accounting II }\end{array}$ \\
\hline \multirow[t]{4}{*}{ A } & 4 & - & - & - \\
\hline & 3 & - & - & - \\
\hline & 2 & $1 * 2=2$ & $1 * 2=2$ & $6 * 2=12$ \\
\hline & 1 & $7 * 1=7$ & $7 * 1=7$ & $12 * 1=12$ \\
\hline TOTAL & & $9 / 70 * 100 \%=12,9 \%$ & $9 / 70 * 100 \%=12,9 \%$ & $24 / 120 * 100 \%=20 \%$ \\
\hline \multirow[t]{4}{*}{ B } & 4 & - & - & - \\
\hline & 3 & - & - & - \\
\hline & 2 & - & - & $6 * 2=12$ \\
\hline & 1 & $7 * 1=7$ & $7 * 1=7$ & $12 * 1=12$ \\
\hline TOTAL & & $7 / 70 * 100 \%=10 \%$ & $7 / 70 * 100 \%=10 \%$ & $24 / 120 * 100 \%=20 \%$ \\
\hline \multirow[t]{4}{*}{$\mathrm{C}$} & 4 & - & - & - \\
\hline & 3 & - & - & - \\
\hline & 2 & - & - & $4 * 2=8$ \\
\hline & 1 & $7 * 1=7$ & $7 * 1=7$ & $12 * 1=12$ \\
\hline TOTAL & & $7 / 70 * 100 \%=10 \%$ & $7 / 70 * 100 \%=10 \%$ & $20 / 120 * 100 \%=16,7 \%$ \\
\hline \multirow[t]{4}{*}{$\mathrm{D}$} & 4 & - & - & - \\
\hline & 3 & - & - & - \\
\hline & 2 & - & - & - \\
\hline & 1 & $7 * 1=7$ & $7 * 1=7$ & $12 * 1=12$ \\
\hline TOTAL & & $7 / 70 * 100 \%=10 \%$ & $7 / 70 * 100 \%=10 \%$ & $12 / 120 * 100 \%=10 \%$ \\
\hline \multirow[t]{4}{*}{$\mathrm{E}$} & 4 & - & - & - \\
\hline & 3 & - & - & - \\
\hline & 2 & - & - & - \\
\hline & 1 & $2 * 1=2$ & - & $12 * 1=12$ \\
\hline TOTAL & & $2 / 70 * 100 \%=2,9 \%$ & - & $12 / 120 * 100 \%=10 \%$ \\
\hline \multirow[t]{4}{*}{$\mathrm{F}$} & 4 & - & - & - \\
\hline & 3 & - & - & - \\
\hline & 2 & - & - & - \\
\hline & 1 & $1 * 1=1$ & - & $6 * 1=6$ \\
\hline TOTAL & & $1 / 70 * 100 \%=$ & - & $6 / 120 * 100 \%=5 \%$ \\
\hline SUM & & $\begin{array}{l}33 / 420 * 100 \%= \\
7,85 \%\end{array}$ & $\begin{array}{l}30 / 420 * 100 \% \\
7,14 \%\end{array}$ & $\begin{array}{l}98 / 840 * 100 \% \\
11,66 \%\end{array}$ \\
\hline
\end{tabular}


Based on Table 4.3 and 4.4 can be seen that the creative thinking ability of the content contained in the curriculum of College accounting courses, in particular, intermediate financial accounting and Advanced were represented by the University of Indonesia (UI) as PTN majoring in accounting with best and Gunadarma University (UG) as PTS with finest accounting department, i.e. still below 20\%. Creative thinking content contained in the curriculum as well most are still at the low criteria (benchmarks).

From the tables found that the amount of content creative thinking skills within the intermediate financial accounting curriculum in UG is smaller than UI. Where is UG $(11,11 \%)<$ UI $(14,16 \%)$ Whereas for advanced financial accounting, Gunadarma University (UG) also smaller than University of Indonesia (UI). Where is UG $(8,47 \%)>\mathrm{UI}(11,66 \%)$.

To know the opportunities of applying creative thinking skills within the accounting curriculum can be seen in Table. 5 more complete is provided by table TOWS analysis of the opportunity.

TABLE 4.4. TOWS ANALYSIS TOWARdS APPLICATION OF CREATIVE THINKING SKILLS OPPORTUNITIES

\begin{tabular}{|c|c|c|}
\hline & \begin{tabular}{ll} 
& \multicolumn{1}{c}{ Strength } \\
A curriculum that \\
supports creative \\
thinking \\
Considerable Education \\
Fund \\
- Many Student achievers \\
in domestic and abroad \\
- Lots of product \\
innovations by the son \\
of the country's famous \\
The availability of \\
natural resources that \\
support \\
Open with experience \\
$-\quad$ & Power high imagination \\
Technology support
\end{tabular} & \begin{tabular}{ll}
\multicolumn{1}{c}{ Weakness } \\
The curriculum has not \\
been run well \\
- $\quad \begin{array}{l}\text { Use of funds not yet } \\
\text { thorough education }\end{array}$ \\
- & Less spirit \\
- & Easily influenced \\
cultures outside \\
- & Lack of initiative seeks \\
information \\
- Fear of taking risks and \\
failing \\
Too rely on logic \\
- $\quad$ Lack of soul competency
\end{tabular} \\
\hline $\begin{array}{ll}\text { Opportunities } \\
\text { The number of countries } \\
\text { that implement the } \\
\text { education system-based } \\
\text { higher-order thinking } \\
\text { - The national education } \\
\text { goals which supports } \\
\text { The world of work that } \\
\text { allows one to innovate } \\
\text { The existence of MEA } \\
\text { open Opportunities to } \\
\text { compete with Other } \\
\text { countries } \\
\text { Opportunity to become } \\
\text { solicitor } \\
\text { The increasingly } \\
\text { sophisticated } \\
\text { technologies }\end{array}$ & $\begin{array}{l}\text { SO Strategy } \\
\text { Increase the educational } \\
\text { system to suit the } \\
\text { purpose } \\
\text { Sharpen the creativity of } \\
\text { students facing the } \\
\text { world of work } \\
\text { Encourage students to } \\
\text { continue to innovate in } \\
\text { order to compete in the } \\
\text { era of globalization } \\
\text { Prepare MEA }\end{array}$ & $\begin{array}{l}\text { WO Strategy } \\
\text { Run curriculum properly } \\
\text { to fit the purpose at the } \\
\text { national } \\
\text { Help students develop } \\
\text { creativity in order to face } \\
\text { the world of work } \\
\text { Develop the power of } \\
\text { reason and imagination } \\
\text { with technology }\end{array}$ \\
\hline \begin{tabular}{ll}
\multicolumn{1}{c}{ Threat } \\
- & It supports lack amenities \\
The lack of competence of \\
teachers \\
Bureaucracy that makes it \\
difficult to convey new \\
ideas of students \\
The era of globalization \\
allowing competition with \\
other nations \\
Culture from the outside \\
that affect lifestyle \\
Socio-economic status- \\
unequal \\
The community's \\
stereotypes \\
Misuse of technology
\end{tabular} & $\begin{array}{l}\text { ST Strategy } \\
\text { Improve support } \\
\text { facilities with } \\
\text { educational funds } \\
\text { available } \\
\text { Sharpen the creativity of } \\
\text { students facing } \\
\text { competition with other } \\
\text { countries } \\
\text { Fix the bureaucracy in } \\
\text { order to support the } \\
\text { idea-gasan new with } \\
\text { fixing the education } \\
\text { system }\end{array}$ & $\begin{array}{l}\text { WT Strategy } \\
\text { - Use the facility of } \\
\text { education to run } \\
\text { curriculum properly } \\
\text { Makes globalization } \\
\text { as a trigger for } \\
\text { passion for } \\
\text { competence } \\
\text { The outside cultural } \\
\text { influences referable to } \\
\text { encourage creating } \\
\text { new things } \\
\text { Increasing the } \\
\text { competence of } \\
\text { teachers to sharpen } \\
\text { development power } \\
\text { of creativity of the } \\
\text { child }\end{array}$ \\
\hline
\end{tabular}

\section{CONCLUSION \& SUGGESTIONS}

Based on the results of the above description, it can be concluded that the application of creative thinking about the content into the curriculum of College accounting charge in Indonesia is still classified as low, but to a level that was supposed to be at the Level of High-Order Thinking, opportunity applying the content is quite elevated.

Suggestions in this study are that the implementation of the curriculum in Indonesia, particularly accounting should follow the demands of the times.

In this 21 st century, students are expected to be on the Level of High-Order Thinking, which is the highest level on the ability to think creatively. So the students are able to compete with other developed countries.

Conventional thinking educators and the public about the negative stereotype something unused often makes students fear their imagination, and innovation creates new inventions so that the resulting product is always just the same; therefore, the educator as the mediator between the curriculums with the learners should be able to dispel the perception and sharpen their thinking ability.

The curriculum in Indonesia should be able to be a facilitator for learners to achieve the expected level. Moreover, the opportunity to apply creative thinking about the curriculum content of accounting in Indonesia is high enough, then we recommend that you charge the augmented content into the curriculum at this time.

\section{REFERENCES}

[1] Albrecht WS, Sack RJ. Accounting education: Charting the course through a perilous future. Sarasota, FL: American Accounting Association; 2000 Aug.

[2] Birrell B. The changing face of the accounting profession in Australia.

[3] K. Ananiadou and M. Claro, "21st century skills and competences for new millennium learners in OECD countries," OECD Educ. Work. Pap., no. 41, p. 33, 2009.

[4] P21, "1st Century," pp. 1-7, 2002.

[5] N. Chabrak and R. Craig, "Student imaginings, cognitive dissonance and critical thinking," Crit. Perspect. Account., vol. 24, no. 2, pp. 91-104, 2013.

[6] S. G. Isaksen and S. J. Pranes, "Crriculum planning for creative thinking and problem solving," J. Creat. Behav., vol. 19, no. 1, pp. 1-29, 1985.

[7] Taba, H. (1962). Curriculum development: Theory and practice. New York: Harcourt, Brace \& World

[8] M. Sc, "Kurikulum Program Studi S-1 Akuntansi : Antisipasi Ca."

[9] K. For, "Value r," Lifelong Learn., no. 1, 2003.

[10] S. Bailin, "Critical and Creative Thinking," Informal Log., vol. IX, no. 1, pp. 23-30, 1987.

[11] D. R. Krathwohl, "A revision of Bloom 's taxonomy: An overview," vol. 41, no. 4, pp. 212-219, 2002. 